\title{
INTRODUCTION
}

I am going to share pieces of my life that are relevant in explaining why it became so disorderly. I come from a long line of prostitutes, alcoholics, drug addicts, thieves, pimps and dysfunction of one sort or another. I pretty much did not have a chance right from the womb, and it is no one's fault. It was my destiny. It was the way life would be for many years. My dad moved off the reservation and that is when my life would drastically change.

Had my parents known our lives would become so lost perhaps they would have made different decisions. I have heard people blaming their families, in particular their parents, but I am not one of those people. First of all, my parents are not here to defend themselves nor should they have to. Second of all, it was my choice to become a prostitute, an alcoholic with a drug problem, a thief and a prisoner. What I mean by 'choice' is that it was all that I knew, I was not taught anything different and this life became easy to fall into. For example, for me, being on the street was just like when a person gets up and goes to their office job in the morning - I would get up, do my drugs to get through the day and then go off to the bar to my job as a prostitute. By choice I mean that no one forced me to do drugs or sell sex and I do not blame my parents for what I experienced. However, the abuses I suffered as a child did lead me to this life - as a way to cope.

As my addictions kicked in so did my need for money to feed them. I would go to any length to get the things I needed whether they were illegal or not. It did not matter to me. I would live in this world and began my addictions at a very young age and I would continue using into my early thirties. I did not think for a moment about the damage the drug and alcohol use did to my family or to me. My life was dark, forlorn and I would lived in a fog for years. I am going to speak about the sexual abuse that I believe hindered my life. It is important.

\section{SEXUAL ABUSE}

I was sexually abused from the time I was three years old until I was eleven. We always tell our children to stay away from strangers - but it was not a stranger that molested me - it was three of my uncles. I had no idea it was 
wrong. I would also be told not to tell anyone or bad things would happen to my family. I was also given money to keep quiet. This abuse was at times violent. I remember being so afraid when in the presence of these uncles. That fear led me to learn how to hide and cope with my pain. I would learn to bury the past. I would become an addict. I would abuse myself in all ways possible. I would go as far as attempting to take my own life.

At the age of six I knew what a penis looked like, tasted like, felt like and smelled like. At six, little girls should be playing with dolls and running freely, enjoying their childhood. At six I was a prostitute to my uncles. I wanted to die. I wanted to crawl into the ground and just stay there. I hated myself. I was only six years old. As I matured, I remember thinking that every man who ever came into my life would meet my wrath for what my uncles did to me. They sexually violated me in every way possible and I had no choice but to let them. I was their whore to do with as they so pleased. My wrath would be stronger with age and I was on a mission of total destruction. This is a long story made short. I would become an addict, a prostitute, a thief, a poor mother, a bad lover and it was absolutely a direct result from the sexual abuse I suffered as a child. There is no doubt in my mind. My life path was made for me - it was my destiny.

\section{ADDICTION: A WORLD ALL OF ITS OWN}

I would begin my addictions at the age of thirteen. I would start by drinking and smoking marijuana. At the age of fifteen I would try my first intravenous drug. By the time I was seventeen I would be a full-blown addict/alcoholic. By the time I was eighteen I was working the street as a prostitute. My life was riddled with darkness. I did not know then that there could be an alternative pathway in life. I cannot imagine how I even survived and lived through this time. I just accepted things as they were because it is all that I knew. There was no other way. It was my 'normal'. The hardest thing for me was becoming a prostitute because it triggered the dark times spent with my uncles. Therefore, I stayed drunk and/or high in order to cope. I could not stand what I became. I hated my uncles and I would never forgive them for what they did to me. I firmly believe my life happened because of the sexual abuse I suffered as a child.

I would also never have a normal relationship. Although I would get married, it was merely out of spite and not true love. Everything that I did in 
my life was directly related to the past events of my life. Alcohol and drugs would be my lover, my friend, my comrade, my mentor and would never be my judge. These things would keep me at bay and would keep me silent, calm and somewhat sane. I drank and did drugs to bury my pain, to bury my life. I did not want to remember and when I did I would drink more or drug more to get rid of the feelings.

I lived for drugs. I lived for alcohol. Men were not important but I would use them when I needed to. I would never feel passion. I would only have two orgasms in my life because I had learned to turn myself off sexually. It was the way my life would be lived. It was my world. It was my normal. It was how I functioned on a daily basis from the time I was thirteen until I was in my early thirties. At the age of eighteen, I would begin my journey in and out of jail.

\section{GOING TO JAIL}

I had never really done any serious jail time. Then again, I had not been caught for everything that I had done. At times I had come so close to taking another human life, but something always stopped me. I began my jail career in 1971 and the last time I was in was 1986 - fifteen years of my life were spent in and out of jail. Being inside was merely a rest for me. I was a drug addict with an alcohol problem. I also practised bulimia while I was in jail and when I was released it would stop. I was bulimic because I did not want to get fat in jail and I was not used to having access to food all of the time. Compared to what I was used to, the food was really good and there was lots of it. However, there was a point just before I sobered up where I was approximately 250 pounds and the bulimia would stay with me for around a year. Once, I did some research on the negative effects of bulimia and only then did I reach out for medical care.

I would like to share one of the first times I would not pass go and where I went directly to jail. I was eighteen or nineteen years old and I received nine months in jail for theft over a $\$ 1000$. When I was using drugs I felt like I was invisible and/or invincible, and I would often steal clothes. I failed to notice a former acquaintance who was working in the store as a "floorwalker" - an individual who walks around a store pretending to shop but actually watching for thieves. I used to spend time and use drugs with this woman, and now I would be caught stealing right under her nose. I was very embarrassed. 
All I could think of was the dope I would be missing out on and how I'd be in jail over the weekend. I attempted to act tough and I played the part. I could not be kind because it was not a part of who I was at that time. I had a reputation to uphold and so I did. Eventually I came down and I was sick. This was my first time getting caught and my first time in jail. The judge gave me nine months in jail. At first I was afraid because this would be my first stint in jail, but I became unconcerned after some time. Initially, I had no idea what to expect and I had a fear of the unknown. The plane ride to Pine Grove was horrifying. We stopped everywhere to pick-up fellow prisoners. The plane reeked because some of the men hadn't bathed for some time. I was lucky that the matrons at the RC buckets - a slang term we used to refer to RCMP cells - let me wash up before I left. I kept thinking that every time we stopped, that I should make a break for it. But then what would I do? I just could not stand the fact that I was going to jail. It started to sink in - the fear set in hard and fast. That was it. Do not pass go, do not collect your \$200, and go directly to jail.

I had no idea what "the Grove" would be like. It turned out to be a duck walk. It was very easy time compared to the life I was living on the streets. However, it was embarrassing because once we arrived we had to be checked for lice and communicable diseases. I felt that I was now just a number, a statistic. The only thing I really disliked was when the matrons would call us by our last names. I have no idea why this bothered me so much, but it did. For the most part the matrons were okay. At Christmas time they brought in all kinds of treats. However, I felt like I did not have the social skills to respond to that type of kindness. As a result of my experiences, I had little compassion and I did not know how to treat anyone outside the realm of my cold desolate world. I did not have any goals or life inhibitions. I did not see myself in a good way at all. For that matter, I was cursed to live an immoral life. My life would become as black as my heart.

The longest stretch I did was about a year, give or take a few months. At this point in my life, I liked jail because I was tough and jail gave me status, a name so to speak. I was the girl. People would move when I walked by. It is intense what that kind of power does for a person. I really believed that I was somebody. People would talk about me like I was a threat and I loved it. I thrived on it. I misused and took advantage of my power. For example, if I saw a man I liked who already had a woman, I would not care, I would just take him for a night or two. When I was done I would kick him to the curb. 
I would take things that were not mine just because I could. There would be neither rhyme nor reason for the things I did.

I met a lot of my street sisters in jail - I wanted so much to be just like them. I would look at them and think, "I have to be like that. I want to be that fierce!" I wanted to be feared. I wanted to be noticed when I walked into a room. I wanted people to move when I walked by. Some did already but I wanted them all to move. I wanted all the power that I could possibly get. I had some of what they had but I wanted more. I always wanted more. I wanted the Devil himself to bow to me. I wanted people to look up to me and to worship me. I wanted to be the most important woman around. I wanted to be dangerous. But who I really became was a full-time loser and nothing more. What is even sadder is that I only became all these things to myself. I was the enemy. I feared me. I moved out of my own way. I was my own worst enemy and it all passed me by like two ships in the night. I had no idea where my ship was heading but most assuredly it would be destructive. What I mean by passed me by is that my life just walked out the back door. From the time I was three years old until I became sober in my early thirties life passed me by. I did not care what happened to me. I did not care what I did to others. And before you know it, I was old and missed my life as it went by. I did not have a childhood, I was not able to be a teenager and I skipped right ahead to being old. My life passed before my eyes.

\section{USING DRUGS IN JAIL}

I spent countless birthdays and Christmases inside. Jail became my home away from home and a place that I felt almost comfortable being in. I had no fear of jail. I even felt safe there - I had three meals a day, a bed and I was not living on the streets. However, if we could acquire drugs inside we used them. I overdosed once after injecting. I never thought that I could have died right there in that jail cell. I am thankful my girls looked after me. Despite nearly dying from an overdose, I would continue to use drugs. In those days it was pretty easy to get drugs on the inside - prescription medication was the prison's way of controlling us. If they kept us subdued it was easier to live with us.

Once, while we were preparing for a Halloween dance, I had my friends save me their prescription drugs for two weeks or more. I was given Valium pills, which knocked me out because I was not used to them. I took them 
four times a day and I was on my back for most of it. To be very honest I don't even know why I was on them but I got them so I thought "what the hell, I may as well enjoy the perks". I had taken about 30 or 40 pills - and I was severely tethered to say the least. I never did anything with caution. My girls looked after me again.

I also did a few months in a 'joint' in Burnaby called "Oakalla". This was a seriously rank joint. It was co-ed but we never saw the men except for on the bus. I was waiting for my court date in an old, rickety building that smelled and felt damp. It was one of those places that should have been torn down rather than used to incarcerate people. It was here that I met other women who revelled in the reputation of being tough. I tried so hard to find my place in this world and just kept having setbacks. There was no place for me, not even in jail. There was never any end to the destruction of my life. I held such a fear in my heart that I cannot explain, but it was there. I so wanted to be loved. I wanted a life. I wanted to be married with 2.5 children and a house with a white picket fence. Seriously, I wanted to be good but I didn't know what to do or how to do it. I so wanted to be accepted. So I did whatever I was asked. I very rarely said "no". I lived in a constant state of fear that I thrived on and I prospered from, but only by negative means. The drugs and alcohol kept me in this frame of mind, whether it was on the street or in jail. It was all that I lived for and it was all that I knew. Some days I would just sit in my cell all alone. I just wanted to be alone. I would take a book and just read to fight off the insanity. I would wish for death but it never came.

\section{ON SEGREGATION AND ATTEMPTING SUICIDE INSIDE}

Time after time I went to jail for alcohol and/or drug related offences. I was constantly living with self-harm and I lived close to the edge. I wanted to die and I tried to kill myself but it didn't work. I would yearn for death but it would not come. After an argument with a guard I tried to hang myself because I was so angry. I let this matron (guard) push me to the edge and when I fought back she had to call for assistance to lock me back in my cell. I was confined to my cell for ten days following this incident.

The worst part of jail was being segregated. Segregation was a small hollow place with nothing more than a bed, three walls and bars as a door. There was a sink and a toilet. It was a very degrading place but it was 
used as a tool to ensure the personal safety of the guards from women who resisted in some way. If we tried to self-harm, then off to segregation we would go and sometimes we would be made to wear a baby doll. A baby doll is a contraption like a straight jacket so you are not able to kill yourself. I would spend many days in segregation for one thing or another. There would be some days that I would want to go to segregation just to get away from the madness and away from myself. There was no hope, there was only fear. I longed for love and it was not there. I longed to be held and to be nurtured but it was not there. No one told me about life or how it should be and I just walked in darkness. I wanted my mother but she died when I was eighteen. Simply put, the day my mother died, I died. She was the best thing I ever had and the sad part is I never had a chance to tell her. I was totally uninspired with life. I would do my best to cover the real Sharon by hiding behind my fear and portraying myself as a tough broad. What I lacked the most was my sense of self and/or self-identity. I really didn't know who I was. I knew who I thought I was, but it was not the real me. I didn't want to be an Indian because of the extreme racism my people faced and I knew I couldn't be white, so who could I be? I felt only isolation of the body, mind, soul and spirit.

I responded to these feelings by smashing up my cell, yelling, screaming and carrying on. No one came to check on me. I was sitting on the floor of my cell crying wondering what I should do - I was emotionally spent. I decided to hang myself, and began to rip up a sheet, tie it in knots, wrap it around my neck, tie it to the bar in my closet and proceeded to sit to the floor. I could feel my breath leaving, my neck was sore and I was seeing stars. I could feel my eyes popping and I was gurgling to catch my breath. I closed my eyes and waited for death to come. I was happy I was finally going to be at peace. The next thing that happened was that I hit the floor with a great crash. The bar was not strong enough for my weight and it snapped in half. I just sat there crying and laughing all at the same time because I didn't even know how to kill myself.

\section{STARTING TO THINK DIFFERENTLY}

What I hated most about jail was the slamming of the cell doors, the bells and other noises. It drove me nuts. To this day I hate bells. The matrons had a bell and they would walk up and down the corridor waking us up. It 
was like being in a black hole - a deep, dark and black hole - an endless pit of self-mutilation and horror. I used to be so scared but I would never let anyone know. I was too solid. I could never show my weakness, as it was not acceptable. To be weak was extremely not cool. At night, sometimes I would curl up on my bunk and cry. When I first went to jail in Prince Albert, Saskatchewan there were no axe murderers or serial killers - it was just women with troubled lives. The sad truth is that I was comfortable in jail. Bells, rules, lights, uniforms and regulations conditioned me. I held myself together so well inside but as soon as I was out it was pure hell in a matter of time. The day that I would get out I would turn to drugs and alcohol - same old, same old. If anything I was consistent. I firmly believe that had I not spent all those times in jail I might be dead.

My world was not normal, as we have figured out thus far. I was a hardcore drug addict with an alcohol issue and nowhere to go. I was alone and I was lost. In all honesty jail was my normal. The street was my normal. Stealing was my normal. Prostitution was my normal. My troubled life was my normal. I felt like I was on an assembly line. I wrote long hopeless letters to my sister-in-law and brother explaining my situation, and how much I was going to change once I got out. It was a never-ending story that was always the same. I always promised that this time I would go straight. It became cyclical and meaningless. The first thing I would do once I got out was go straight to the pusher man. It's all I knew how to do. But there was this fire, this ember deep in my soul. I did want change but I had no idea how to get it. I continued to make empty promises, not only to myself but also to my family. Those promises were as hollow as my head. I had lots of friends in jail and that is all you needed. In jail, I had a name. I was somebody.

One of the most difficult things for me was the loss of my children. I had a baby at seventeen and another at twenty-three, and my last child at thirty years of age, but my addictions were stronger than my mothering skills. I lost two of these children to the system and would continue to feel an insane guilt for most of my life. I buried this in a sea of addictions so as to not feel the hurt. I would pay the piper. I would feel so much guilt that it nearly killed me. In turn my children would meet the wrath of the world and their lives began to mirror mine, which only added to my feelings of guilt. I had gone astray. I felt like there was no one there to hear my screams. When my cell closed at night I would just lie in that six-by-six foot concrete 
room, wondering where had I gone wrong and why? I would do dope if it was there and if not, I would cry myself to sleep like a baby. My toughness would be shed like the skin of a snake and would return when the cell doors slammed open in the morning. There was no room for weakness, but at night when the cell doors shut so did your life as a woman. The weakness would arise like the moon and set like the sun. The emptiness that hid there was insurmountable and devastating to the body, mind, and soul.

Christmas in jail had to be the worst of all. It was lonely, boring, maddening, sickening, deadening, hopeless, remorseful, and mostly - it was desperate. There were no calls, no visits, nothing. It was just girls all feeling the same way about a day that is supposed to be the best day of the year. You felt totally alone. There have been many, many lonely moments in my life. It would take many years to find 'me'. Once I became sober, my journey would not be easy.

And then a miracle happened. I stayed alive. I survived. I would say these words, "Hello, my name is Sharon Acoose and I am an alcoholic with a drug problem". That simple statement would change my life. It would be the best thing I could have ever done. I would learn to deal with all my pain. I would learn to deal with all the ills and my life would change over time. I am alive. I am sane. Most importantly I am sober with no drug addictions.

\section{CONCLUSION}

Ah yes, I rose from the ashes! Each day that I am still on top of the earth is a good day. I have eighteen years of sobriety. I have a Bachelor of Arts degree in Human Justice (1993). I have a Master's degree in Social Work (1995). And, I am presently enrolled in a Doctorate of Philosophy through the University of Saskatchewan, College of Medicine in Community Health and Epidemiology. I never thought any of these things would be at all possible. You know I thought I would be dead before I was twenty and I am now fifty-six. I am neither special nor unique, but these experiences are miraculous. I lived a long, hard and colourful life but it was all worth it. There truly is life after death. I have proven to myself what I can accomplish and I will never stop learning. I love who I am today.

I have forgiven myself for my wrongs - I had to in order to heal. I have

a pretty good life today. I have full connection with my youngest daughter and her five children. I have partial connection to my eldest daughter but no 
connection with her five children. And, I have partial connection with my son who has no children. All I can say is that I continue to feel for what I did to my children and for the sexual abuse I suffered as a child, but now, I feel free. I feel so nourished. In order to not die I had to let go of my past and I have. I came from the ashes.

\section{ABOUT THE AUTHOR}

Sharon Acoose served provincial sentences over a number of years in Canada, and has since gone on to complete an undergraduate degree in Human Justice and an Master's degree in Social Work from the University of Regina. She is currently working on her Ph.D. and is Assistant Professor of Social Work at the First Nations University of Canada. She is actively involved in a national research project spearheaded by Dr. Colleen Anne Dell that is investigating the role of stigma and identity in Aboriginal women's healing journeys from problematic substance use. 